\title{
In-Vitro Evaluation of Bio-control Agents against Alternaria Leaf blight of Sunflower and Vascular Wilt of Beans
}

\author{
Bushra Rasool, Baby Summuna*, T.A. Shah and Umbarkar Pooja \\ SKUAST- Kashmir, India \\ *Corresponding author
}

\section{A B S T R A C T}

\section{Keywords}

Bio-control agents, Beans, Fungus, Sunflower

\section{Article Info}

Accepted: 04 July 2019 Available Online: 10 August 2019
Four fungal bio-control agents, viz., Trichoderma harzianum, T. viride, Aspergillus spp. and Tricothecium spp. were evaluated in vitro through dual culture technique against Alternaria helianthi, the causative agent of leaf blight of sunflower and Fusarium oxyporum $\mathrm{f}$. sp. phaseoli, the causative agent of vascular wilt of beans. The observations were taken after fourth and seventh day for both the pathogens. After fourth day, observations recorded in case of $A$. helianthi, the minimum colony diameter $(0 \mathrm{~cm})$ and maximum inhibition percentage over control $(100 \%)$ were observed in Trichoderma harzianum and $T$. viride which were statistically at par with Aspergillus spp. and Tricothecium spp. while after seventh day, the result was more or less similar. The minimum colony diameter $(0 \mathrm{~cm})$ of pathogen were observed in Trichoderma harzianum and T. viride with maximum inhibition per cent (100\%) over control, which differed statistically from Aspergillus spp. Tricothecium spp. showed least effectiveness against the target pathogen showing colony diameter $(2.3 \mathrm{~cm})$ and inhibition $(23.33 \%)$ after fourth day and colony diameter $(4.5 \mathrm{~cm})$ and inhibition (35.71\%) after seventh day over control. After fourth day, the observations taken in case of $F$. oxyporum $\mathrm{f}$. sp. phaseoli, the minimum colony diameter $(1.6 \mathrm{~cm})$ and maximum inhibition per cent over control (77.14\%) were observed in $T$. harzianum which were statistically at par with $T$. viride, Aspergillus spp. and Tricothecium spp. After seventh day the result was more or less similar. The minimum colony diameter $(1.2 \mathrm{~cm})$ of pathogen was observed in $T$. harzianum with maximum inhibition percentage $(86.66 \%)$ over control, which differed statistically from $T$. viride and Aspergillus spp. Tricothecium spp. showed least effectiveness against the target pathogen showing colony diameter $(3.5 \mathrm{~cm})$ and inhibition per cent $(50 \%)$ after fourth day and colony diameter $(3.0$ $\mathrm{cm})$ and inhibition per cent $(66.66 \%)$ after seventh day over control.

\section{Introduction}

India has rich diversity of annual oilseed crops on account of diverse agro-ecological conditions. Nine annual oilseeds, which include seven edible oilseeds, viz., groundnut, rapeseed-mustard, soybean, sunflower, sesame, safflower and niger and two nonedible crops viz., castor and linseed are grown in the country. Cultivated sunflower (Helianthus annuus L.) is the main source of edible oil. It ranks second to soybean in worldwide vegetable oil production. Commercially available sunflower contains 39 to 49 per cent oil in the seed.

It is extensively grown in Argentina, France, Spain, USA, China, Ukraine and India.

It is primarily grown for edible oil characterized by a high concentration of linoleic acid and moderate level of oleic acid. 
The total area under sunflower in the world is about 25.34 million hectare with the production of 40.04 million tonnes (Anonymous 2012). In India, sunflower occupies the fourth place among oilseed crops in terms of acreage and production. The area under sunflower cultivation in India was 0.72 $\mathrm{m}$ ha, with a total production of 0.50 milliontonnes and productivity of $692 \mathrm{kgha}^{-1}$ (Anonymous, 2013). Over 70 per cent of the sunflower crop is being grown across Karnataka, Maharashtra and Andhra Pradesh. In Karnataka it occupies an area of about 3.84 lakh ha with a production of 1.93 lakh tonnes and productivity of $503 \mathrm{kgha}^{-1}$. Karnataka is the leading state in the country accounting for more than 50 per cent of the total acreage and contributing to 38 per cent of the national sunflower production.

Sunflower is prone to severe damage by diseases especially when there is well spread rainfall and high humidity, efforts to stabilize crop production has not been successful owing to number of diseases encountered on this crop, viz., Alternaria leaf spot/blight, Rust, Downy mildew, Powdery mildew, Phoma leaf spot/blight, Botrytis grey mold, Rhizpohus head spot, Macrophomina charcoal rot, Sclerotium root rot, Fusarium and Verticillium wilts are sporadic in nature and location specific (Gulya and Masirevic 1991). Alternaria leaf spot/blight caused by Alternariahelianthi (Hansf.) Tubaki and Nishihara were first described in 1943 from Uganda. Since then this disease has been reported from almost all sunflower growing countries throughout the world. Two species of Alternaria cause leaf and stem spots on sunflower Alternaria helianthi and A. zinniae, of which $A$. helianthi is the more prevalent and more serious. These diseases can be serious in warm humid environments. Yield losses may occur through reduced head diameters, number of seeds per head, and oil content or quality. The disease is known to cause more than 80 per cent of yield loss under severe epiphytotic conditions in northern Karnataka (Shankergoud et al., 2006) in India. The disease severity is known to increase or decrease depending upon the changing environmental conditions during the crop growth period. A. helianthi is recognized as a major disease in more humid areas of India as well as in Central Europe, Australia, South America and parts of Africa. It occurred in an epidemic form during 1988 in Southern India, especially in Karnataka destroying major area of the crop due to heavy unexpected rain during flowering and grain filling stage of the crop. According to Allen et al., (1981), the nature of yield reduction is determined to some extent by stage of plant growth when disease epidemic develops.

The disease generally first appears on the lower leaves in the form of dark-brown to black spots measuring 0.2 to $0.5 \mathrm{~mm}$ in diameter. The circular to oval spots are surrounded by chlorotic zone with grey-white necrotic Centre marked with concentric rings. The disease spread to middle and upper leaves with the growth of the plants. In advanced stages, elongated spots are formed on petioles, stem and ray florets. Particularly under humid conditions, the spots enlarge in size and coalesce resulting in blightening of leaves and sometimes the flower heads are also infected (Amaresh and Nargund, 2001).

The Alternaria leaf blight is known to infect all aerial parts of plant viz., leaf, petiole, stem, floral parts and seeds. Initially, the disease appears in the form of small, scattered brown spots on the leaf lamina. Later, these spots increase in size and coalesce covering larger leaf area (1 to $2.5 \mathrm{~cm}$ in diameter), with dark brown margin with yellow halo. Linear necrotic lesions also appear on stem, petioles and sepals. In severe cases, the head and seeds also get infected (Kolte and Mukhopadhyay 1973, AnilKumar et al., 1974). 
Pathogen survives on seed, host debris and weed host. Successive crop of sunflower may also help to multiply the pathogen. Hot weather and frequent rain during the milk and wax stages of development favour infection. Disease development is favoured by $25-27^{\circ} \mathrm{C}$ temperatures with at least 12 hours of wet foliage and is reported to spread rapidly during the rainy season (Basappa and Santha Lakshmi Prasad, 2005).

Common bean (Phaseolus vulgaris L.) belongs to family Leguminaceae and is a native to South Mexico and Central America. Dry bean is truly a "new world crop" originating 7000 years ago in different parts of North and South American continents (Landon 2008). It is a major grain legume consumed worldwide for its edible seeds and pods and is an important source of human dietary protein and calories (Pachico, 1993). The crop is consumed principally for its dry beans and green pods. It provides 15 per cent of the protein and 30 per cent of the caloric requirement to the world's population and represents 50 per cent of the grain legume consumed worldwide (Mcconnell et al., 2010). Dry beans are an important functional food containing high levels of chemically diverse components viz., phenols, resistance starch, vitamins and fructo-oligosaccharides giving protection against such conditions as oxidative stress, cardiovascular diseases, diabetes, metabolic syndrome and many types of cancers (Camara et al., 2013). Beans are eaten as boiled, baked, fried, or ground into flour. Crop residues such as dried pods, stems and processing by-products can be used as fodder. Although Phaseolus vulgaris is less efficient in fixing $\mathrm{N}$ than other legumes, yet it is able to fix up to $125 \mathrm{~kg} \mathrm{~N} \mathrm{ha}^{-1}$ and nodulates with several rhizobia (Wortmann, 2006).

According to FAO, production of dry beans was 26.83 million tonnes during 2016 in an area of 29.39 million ha and productivity was 0.91t ha ${ }^{-1}$ with Brazil, China, India, Mexico, Myanmar, Tanzania and USA are main producer of beans in the world Brazil is the leading producer of bean in the world. In India it is grown in an area of 9.47 million ha with a production of 3.90 million tonnes and productivity $0.41 \mathrm{t} \mathrm{ha}^{-1}$ in the states of Himachal Pradesh, Jammu and Kashmir, Kerala, Karnataka, Maharashtra, Tamil Nadu, Uttar Pradesh, and West Bengal and production of green beans was 23.60 million tonnes during 2016 in an area of 1.56 million ha with productivity of $15.5 \mathrm{t} \mathrm{ha}^{-1}$ (Anonymous, 2016).

In India it is grown in an area of 0.23 million ha with a production of 0.66 million tonnes and productivity $2.81 \mathrm{t} \mathrm{ha}^{-1}$ (Anonymous 2016). It is the premier green legume crop of Jammu and Kashmir where its cultivation is mainly confined to rainfed and Karewa areas covering an area of about 26.75 thousand ha with an annual production of 14.2 thousand metric tonnes. As vegetable crop, common bean is grown in Kashmir over an area of 2000 ha with an annual production of 400 metric tonnes (Bhat et al., 2017). The common bean is a warm season legume that does better under tropical, subtropical and temperate conditions and under wet conditions suffers from fungal attacks (Wortmann 2006).

A number of biotic and abiotic stresses like diseases, pests, soil and environmental conditions result in reduction of crop yield. Among diseases, bean rust, angular leaf spot, powdery mildew, halo blight, anthracnose, white mold and Fusarium wilt of bean are prevalent (Junior et al., 2001). Fusarium wilt is one of the most important economic diseases of common beans world over (Okungbowa and Shittu, 2014). In China, Fusarium wilt has caused significant economic losses in common bean production due to increased land pressure to grow crops in monoculture (Xue et al., 2015). The Fusarium 
wilt was first identified on common bean in the USA in 1929 (Harter 1929).It is ubiquitous fungal pathogen causing wilt diseases in a broad range of important crop species such as cotton, banana, tomato, flowers and legumes (Harter 1929). The pathogen can perpetuate in soil for pretty long periods of time and continued cropping of beans result in build-up of fungal pathogen population in soil. Being a seed-borne pathogen, there occurs distant dissemination of the disease (Kendrick and Snyder, 1942).

The mode of infection of pathogen takes place through penetration of plant root tissue, subsequent colonization of the vascular tissues, stem causing xylem blockage, internal stem discoloration and total plant wilt. The main symptoms of beans infected with pathogenic isolates of Fusarium oxyporum $\mathrm{f}$. sp. phaseoli are severe developmental alterations like stunting and complete wilting along with extensive chlorosis and necrosis leading to plant death (Harter, 1929).

The pathogen has been detected in most of the bean-growing regions of the world. Fusarium wilt is also a problem in many other intensively cropped areas which witness high rainfall or rains become more frequent early in the season with climate change and weather variability. High moisture, excessive irrigation or poorly drained fields and a lack of crop rotation are prone predisposing factors for the disease (Harter 1929). The pathogen is soilborne, introduced through infected seeds or contaminated farm implements. The primary symptom is characterized by discolouration of the vascular tissues, loss of turgidity and leaf chlorosis. This is occasionally followed by leaf abscission and/or plant death and manifested on one side of host plant (Schwartz et al., 2005). Infection occurs at seedling stage, impair development and result in stunted growth of plants particularly if infected at a younger age. Fusarium wilt usually appear on medium-aged or older plants and appear as yellowing and wilting of lower leaves that progress until plant turns yellow and are readily observed in the field (Toledo-souza et al., 2012). Optimum temperature for disease development is $20^{\circ} \mathrm{C}$. The roots and stem show discoloration of vascular system that is a diagnostic symptom for Fusarium wilt and after cutting the lower stem a red-brown streak in vascular tissues is observed. The discoloration is usually noticed in plants mostly in lower stem and Optimum temperature for disease development is $20^{\circ} \mathrm{C}$. The roots and stem show discoloration of vascular system that is a diagnostic symptom for Fusarium wilt and after cutting the lower stem a red-brown streak in vascular tissues is observed. The discoloration is usually noticed in plants mostly in lower stem and petiole nodes. Moreover, the roots are partially or totally reddish-brown in color (Kendrick and Snyder, 1942).

\section{Materials and Methods}

Biocontrol agents viz., T. harzianum, T. viride, Aspergillus spp. and Trichothecium spp. were screened for their efficacy against $A$. helianthi, the causative agent of leaf blight of sunflower and $F$. oxyporum $\mathrm{f}$. sp. phaseoli, the causative agent of vascular wilt of beans in the Division of Plant Pathology, SKUAST, Kashmir. The bioassay was done by the dual culture technique given by Morton and Stroube (1955). Seven day old culture discs of $5 \mathrm{~mm}$ diameter each of fungal antagonist and the pathogen were placed at equidistance from the margin of Petri plates $(90 \mathrm{~mm})$ containing Potato Dextrose Agar medium on opposite sides. The plates were incubated for 7 days at $25 \pm 2{ }^{\circ} \mathrm{C}$ in the BOD incubator after inoculation of the pathogen (Wang et al., 2006). A control having only test pathogen was also kept side by side for comparison. Each treatment was replicated thrice. Observations on linear growth $(\mathrm{cm})$ of the test organism up to the 
inhibition zone were recorded after fourth and seventh day and the per cent growth inhibition of test pathogen over control was calculated. Radial growth of the mycelium in Petri plates was measured in two directions at right angles to each other and average of two was expressed as diameter of colony (Lilly et al., 1951). In case of wavy, irregular growth of colony average of the largest and shortest diameter was taken as the growth diameter (Brown, 1923). The radial growth of mycelium was recorded in each treatment after the pathogen covered the media in control and per cent inhibition over control was calculated using the formula (Vincent, 1947).

Per cent growth inhibition= $\frac{\text { C-T }}{\text { C }}$

Where,

$\mathrm{C}=$ Colony diameter of pathogen in control.

$\mathrm{T}=$ Colony diameter of pathogen in treatment.

\section{Results and Discussion}

Four bio agents viz., Trichoderma harzianum, T. viride, Aspergillus spp. and Tricothecium spp. were evaluated by dual culture technique against Alternaria helianthi. The data revealed that all bioagents inhibited the growth of Alternaria helianthi varied from 35.71 per cent to 100 per cent (Table 1). Minimum colony diameter $(0 \mathrm{~cm})$ and maximum inhibition per cent over control $(100 \%)$ were observed after fourth day in case of $T$. harzianum and $T$. viride which were found statistically at par with each other while Aspergillus spp. showed 33 per cent inhibition (2 cm diameter) and Tricothecium spp.23.33 per cent inhibition $(2.3 \mathrm{~cm}$ diameter). After seven days the results were more or less similar to the results of fourth day. The minimum colony diameter $\left(\begin{array}{ll}0 & \mathrm{~cm}\end{array}\right)$ of pathogens was observed in case of $T$. harzianum and $T$. viride with the inhibition percentage of 100 per cent over control which were observed statistically different from Aspergillus spp. and Tricothecium spp. The data also revealed that $T$. harzianum and $T$. viride were actively inhibiting the growth of pathogen in dual culture up to seven days and also the inhibition was more or less same to the inhibition after four days. Tricothecium spp. was least effective biological agent against the target pathogen with $2.3 \mathrm{~cm}$ diameter and 23.33 per cent inhibition after fourth day and with $4.5 \mathrm{~cm}$ diameter and 35.71 per cent inhibition after seventh day over control (Plate 1). This may due to the slow growth of biocontrol agent. The present findings are in accordance with other workers like Vijayalakshmi et al., (2018).

The data given from Table 2 reveals that all bioagents significantly inhibited the growth of F. oxysporum, varied from 66.66 to 86.66 per cent. Minimum colony diameter $(1.6 \mathrm{~cm})$ and maximum inhibition per cent $(77.14 \%)$ over control was observed after fourth day in case of $T$. harzianum, 76.28 per cent inhibition (1.7 $\mathrm{cm}$ diameter) in case of $T$. viride, 62.8 per cent inhibition $(2.6 \mathrm{~cm})$ with Aspergillus spp. and $50 \%$ inhibition $(3.5 \mathrm{~cm})$ with Tricothecium spp. After seven days, the results were more or less similar to the results of fourth day. The minimum colony diameter $(1.2 \mathrm{~cm})$ of pathogen was observed in case of $T$. harzianum with the inhibition per cent of 86.66 over control which were statistically significant than $T$. viride Aspergillus spp. and Tricothecium spp. The data also revealed that $T$. harzianum and $T$. viride were actively inhibiting the growth of pathogen in dual culture up to seven days and also the inhibition was more or less same to the inhibition after four days. Tricothecium spp. was least effective biological agent against the target pathogen with $3.5 \mathrm{~cm}$ diameter and 50 $\%$ inhibition after fourth day and with $3.5 \mathrm{~cm}$ diameter and $66.66 \%$ inhibition after seventh day over control (Plate 2). 
Table.1 In-Vitro evaluation of Bio-control Agents against $A$. helianthi

\begin{tabular}{|l|l|l|l|l|}
\hline \multirow{2}{*}{ Treatments } & \multicolumn{2}{|c|}{ After 4 Days } & \multicolumn{2}{c|}{ After 7 Days } \\
\cline { 2 - 5 } & $\begin{array}{l}\text { Colony } \\
\text { Diameter (cm) }\end{array}$ & $\begin{array}{l}\text { \% Inhibition } \\
\text { over control }\end{array}$ & $\begin{array}{l}\text { Colony } \\
\text { Diameter } \\
\text { (cm) }\end{array}$ & $\begin{array}{l}\text { \% Inhibition } \\
\text { over control }\end{array}$ \\
\hline T. harzianum & 0 & 100 & 0 & 100 \\
\hline T. viride & 0 & 100 & 0 & 100 \\
\hline Aspergillus spp. & 2.0 & 33 & 4.0 & 42.85 \\
\hline Tricothecium spp. & 2.3 & 23.33 & 4.5 & 35.71 \\
\hline Control & 3 & ---- & 7.0 & ---- \\
\hline CD & $\mathbf{0 . 2 3}$ & ------ & $\mathbf{0 . 4 8}$ & --- \\
\hline SE(d) & 0.11 & ----- & 0.22 & --- \\
\hline SE(m) & 0.08 & ----- & 0.15 & ---- \\
\hline CV & 8.19 & ---- & 8.32 & ----- \\
\hline
\end{tabular}

Table.2 In-vitro evaluation of bio-control agents against $F$. oxyporum f. sp. phaseoli

\begin{tabular}{|l|l|l|l|l|}
\hline \multirow{2}{*}{ Treatments } & \multicolumn{2}{|c|}{ After 4 Days } & \multicolumn{2}{c|}{ After 7 Days } \\
\cline { 2 - 6 } & $\begin{array}{l}\text { Colony } \\
\text { Diameter (cm) }\end{array}$ & $\begin{array}{l}\text { \% Inhibition } \\
\text { over control }\end{array}$ & $\begin{array}{l}\text { Colony } \\
\text { Diameter } \\
\text { (cm) }\end{array}$ & $\begin{array}{l}\text { \% Inhibition } \\
\text { over control }\end{array}$ \\
\hline $\begin{array}{l}\text { Trichoderma } \\
\text { harzianum }\end{array}$ & 1.6 & 77.14 & 1.2 & 86.66 \\
\hline Trichoderma viride & 1.7 & 76.28 & 1.33 & 85.22 \\
\hline Aspergillus & 2.6 & 62.85 & 2.0 & 77.77 \\
\hline Tricothecium & 3.5 & 50.00 & 3.0 & 66.66 \\
\hline Control & 7.0 & ---- & 9.0 & ----- \\
\hline CD & $\mathbf{0 . 4 5}$ & ----- & $\mathbf{0 . 5 1}$ & -- \\
\hline SE(d) & 0.19 & ---- & 0.22 & -- \\
\hline SE(m) & 0.14 & ---- & 0.15 & - \\
\hline CV & 7.29 & ---- & 8.32 & - \\
\hline
\end{tabular}


Plate.1 In-vitro evaluation of Bio-control agents against A. helianthi

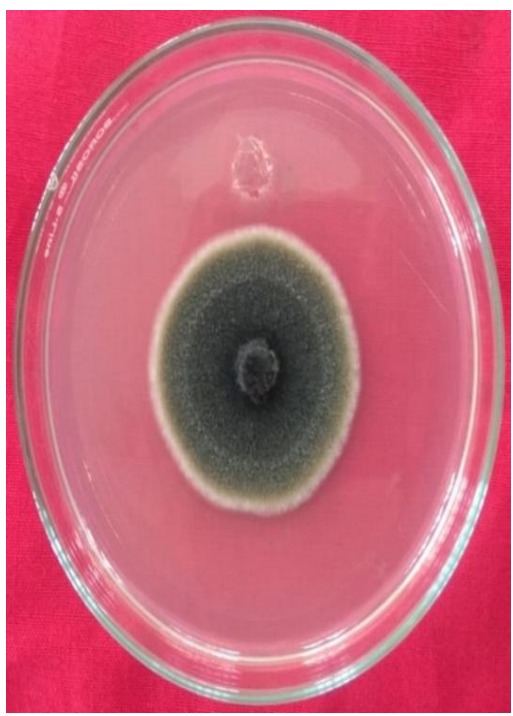

A

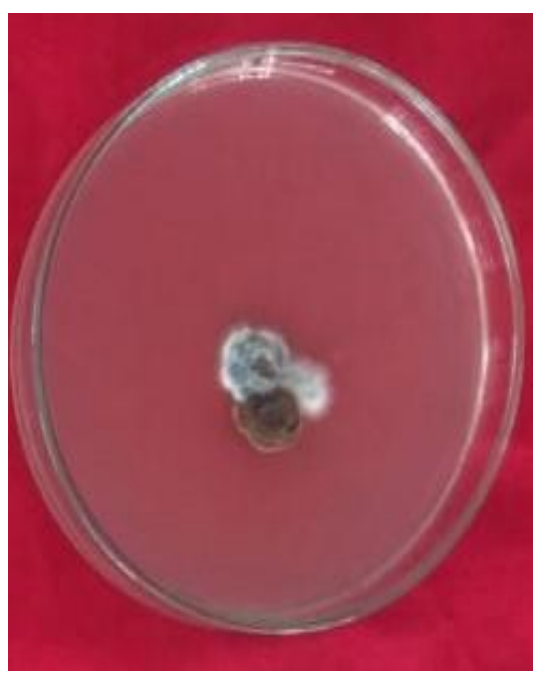

D

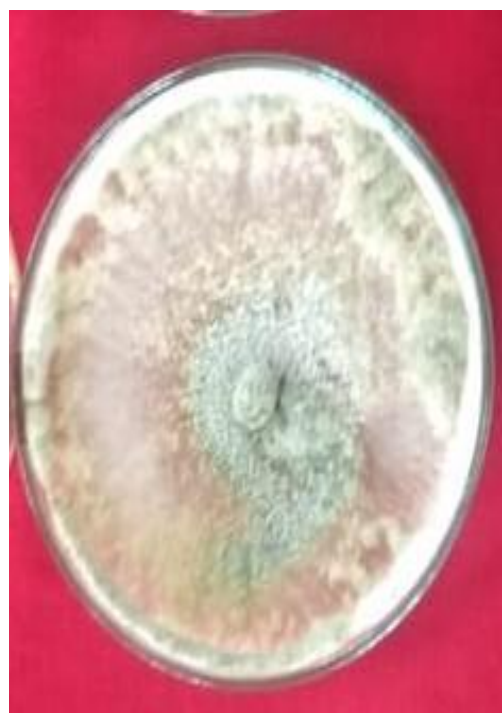

B

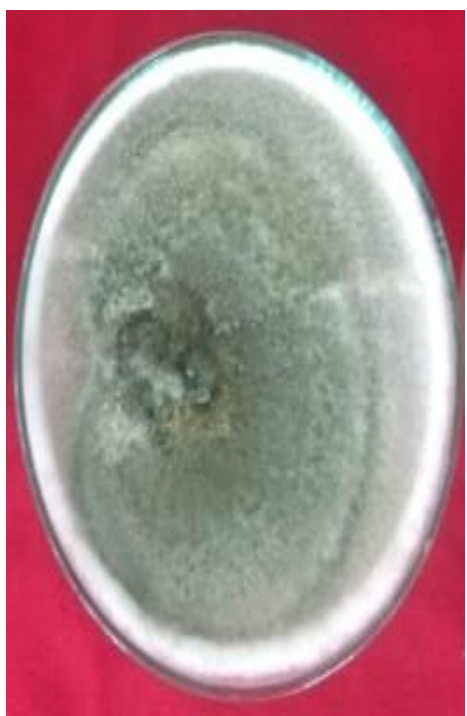

C

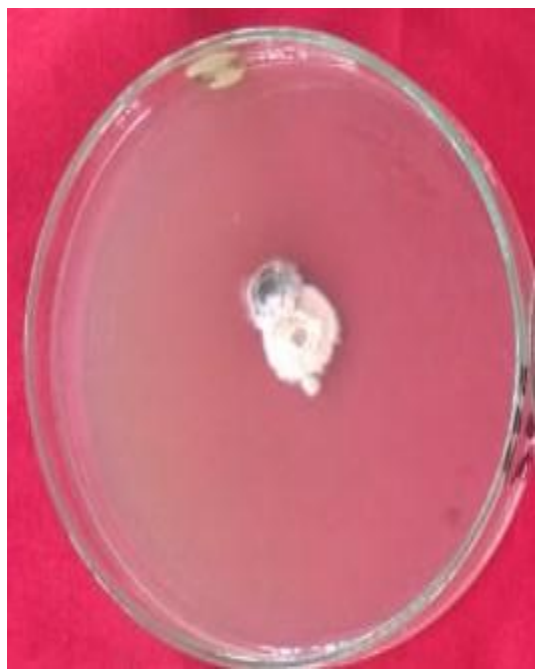

E

A) Control (Pathogen) B) T. viride. C) T.harzianum. D) Aspergillus spp. E) Tricothecium spp. 
Plate.2 In-vitro evaluation of bio-control agents against $F$. oxysporum $\mathrm{f}$. sp. phaseoli

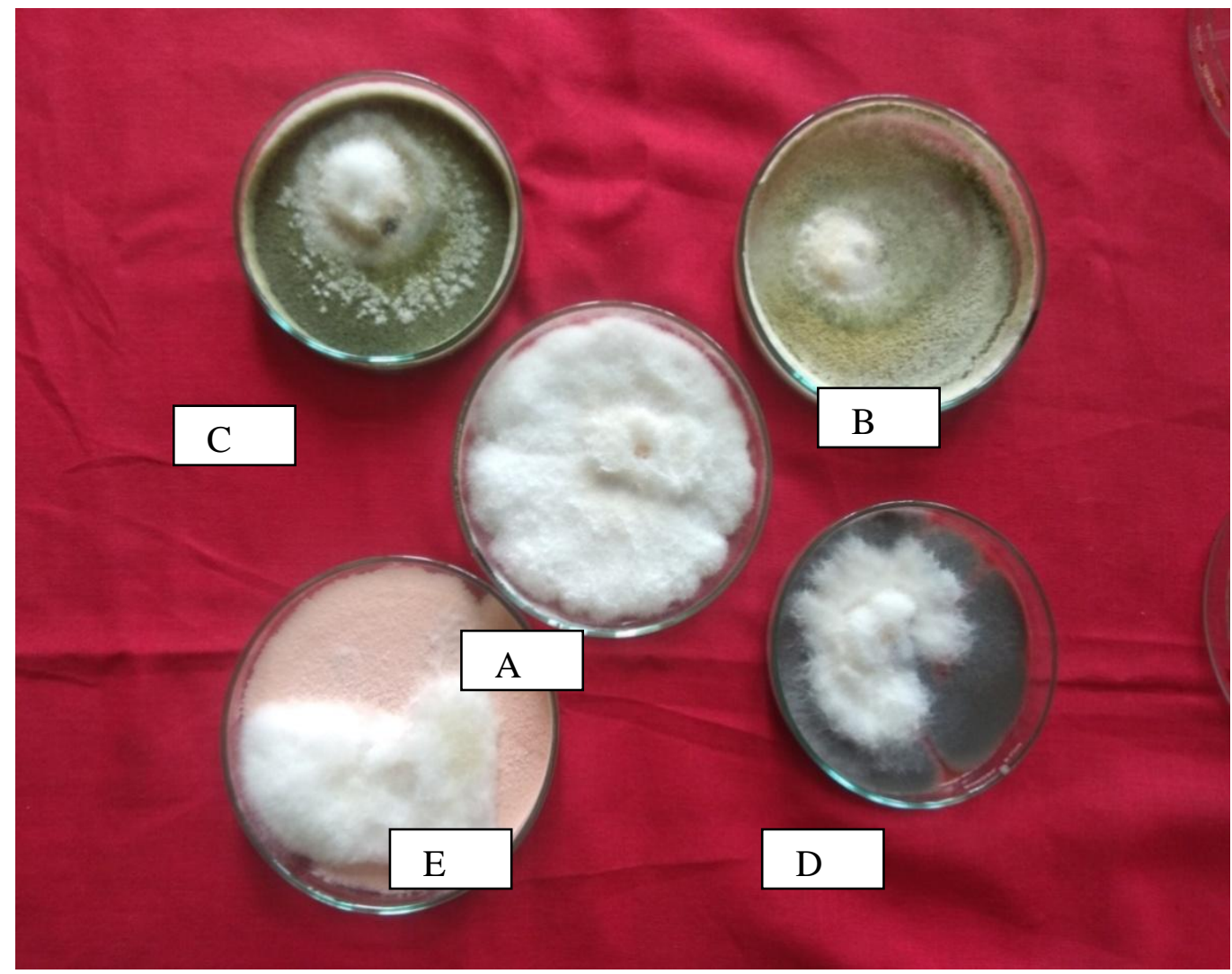

A) Control (Pathogen) B) T. viride C) T. harzianum D) Aspergillus spp. E) Tricothecium spp.

This may due to the slow growth of biocontrol agent. The present findings are in accordance with other workers like Carvalho et al., (2014, 2015).

The present investigation clearly reveals that the use of microbial inoculants offer a practical and alternative method for the management of Alternaria leaf blight in sunflower and vascular wilt of beans.

Use of Trichoderma spp. as biocontrol agent is found most significant in controlling Alternaria leaf blight in sunflower as well as vascular wilt of beans as compared to rest of the bioagents. Use of bioagents is therefore strongly recommended to control these diseases keeping in view their eco-friendly nature and long lasting effect on plant compared to chemical pesticides.

\section{References}

Allen S J, Kochman J K and Brown J F 1981. Losses in sunflower yield caused by Alternaria helianthi in Southern Queensland. Australian Journal of Experimental Agriculture and Animal Husbandry, 21: 98.

Amaresh Y S and Nargund V B 2001. Studies on biochemical changes in sunflower leaves due to infection by Alternaria helianthi (Hansf.) Tubaki and Nishihara. Journal of Maharashtra Agricultural Universities, 26: 344-346.

Anilkumar T B, Urs S D, Seshadri V S and Hegde R K 1974. Alternaria leaf spot of sunflower. Current Sciences, 43: 93-94.

Anonymous 2012. FAO report on oilseedssunflower for the year 2011-12. 
Anonymous 2013. Annual Programme Report of AICRP on oilseeds- sunflower for the year 2012-13, DOR, ICAR, Hyderabad, India.

Anonymous 2016. FAOSTAT. http://foastat3. Fao.org/browse/O/OC/E.

Basappa H and Santha Lakshmi Prasad M 2005. Alternaria Leaf Blight/Leaf Spot. pp. 30-33. In: Hegde DM (ed.), Insect Pests and Diseases of Sunflower and their Management, Hyderabad, Directorate of Oilseeds Research,

Bhat T A, Bhat N A, Bhat H A, Ahanger R A, Wani S H and Dar S A 2017. Status of bacterial blight of common beans (Phaseolus vulgaris L.) in Kashmir. Journal of Pharmacognosy and Phytochemistry, 6: 376-379.

Brown W 1923. Experiments on the growth of fungi in culture media. Annals of Botany, 37:105-109.

Camara C R S, Urrea C A and Schlege V 2013. Pinto beans (Phaseolus vulgaris L.) as a functional food. Implications on Human Health Agriculture, 3: 90-111.

Carvalho D D C, Mello S C M, Martins I and Junior M L 2015. Biological control of Fusarium wilt on common beans by infurrow application of Trichoderma harzianum. Tropical Plant Pathology, 40: 375-381.

Carvalho D D C, Junior M L, Martins I, Inglis P W and Mello S C M 2014. Biological control of Fusariumoxysporum f. sp. phaseoli by Trichoderma harzianum and its use for common bean seed treatment. Tropical Plant Pathology, 39: 221-223.

Gulya J J and Masirevie K 1991. Common names for the plant diseases of sunflower (Helianthus annuus L.) and Jerusalem artichoke (Helianthus tuberosa L.). Plant Diseases, 75: 30.

Harter L 1929. Fusariumdisease of beans. Phytopathology, 19: 84.
Junior W C D J, do Vale F X R, Coelhol R R, Hau B, Zambolim L, Costa L C and Bergamim F A 2001. Effects of angular leaf spot and rust on yield loss of Phaseolus vulgaris. Phytopathology, 91: 1045-1053.

Kendrick J B and Snyder W C 1942. Fusarium yellow of beans Phytopathology, 32: 1010-1014.

Kolte S J and Mukhopadhyay A N 1973. Occurrence of some new sunflower disease in India. Pesticides Abstracts and News Summary, 19: 392-396.

Lilly V G and Barnett H L 1951. Physiology of fungus. McGraw Hill Books Inc. Co., New York, USA.

Mcconnell M, Mamidi S, Lee R, Chikara S, Rossi M, Papa R and McClean P 2010. Syntenic relationships among legumes revealed using a gene-based genetic linkage map of common bean (Phaseolus vulgaris L.). Theoretical and Applied Genetics, 121: 1103-1116.

Morton D T and Stroube W H 1955. Antagnostic and stimulatory effects of micro-organisms upon Sclerotium rolfsii. Phytopathology, 45: 419-420.

Okungbowa F I and Shittu H O 2014. Fusarium wilts: an overview. Environmental Research Journal, 6: 2224.

Pachico D 1993. The demand for bean technology. International Centre for Tropical Agriculture, 128: 60-73.

Schwartz H F, Steadman J R, Hall R and Forster R L 2005.Compendium of Bean Diseases. American Phytopatological Society, 2: 120.

Shankergoud I, Shadakshari YG, Parameshwarappa KG, Chandranath HT, Katti P and Mesta R K 2006. Sunflower and Castor Research in Karnataka - An overview. University of Agricultural Sciences, Dharwad (India), pp. 1-41. 
ToledoSouza E D, Da Silveira P M, CafeFilho A C and Junior M L 2012. Fusarium wilt incidence and common bean yield according to the preceding crop and the soil tillage system. Presquisa Agropecuaria Brasileira ,47: 10311037.

Vijayalakshmi G, Karuna $\mathrm{K}$ and Mahadevaswamy G 2018. Evaluation of Microbial Biocontrol Agents and Fungicides against Alternaria helianthi causing Leaf Blight of Sunflower. International Journal of Current Microbiology and Applied Sciences, 7(01): 2726-2730.

Vincent J H 1947. Distortion of fungal hyphae in the presence of certain inhibitors. Nature, 159: 850.
Wang H, Hwang S F, Chang K F, Turnbull G D and Howard R J 2003. Suppression of important pea diseases by bacterial antagonists. Biocontrol, 48: 447-460.

Wortmann C S 2006. Phaseolus vulgaris L. (common bean). Plant Resources of Tropical Africa, Wageningen, Netherlands, pp. 183- 185.

Xue R, Wu J, Zhu Z, Wang L, Wang X and Wang S 2015. Differentially expressed genes in resistant and susceptible common bean (Phaseolusvulgaris L.) genotypes in response to Fusarium oxysporum f. sp. phaseoli. PLOS ONE, 10: 78- 81.

\section{How to cite this article:}

Bushra Rasool, Baby Summuna, T.A. Shah and Umbarkar Pooja. 2019. In-Vitro Evaluation of Bio-control Agents against Alternaria Leaf blight of Sunflower and Vascular Wilt of Beans. Int.J.Curr.Microbiol.App.Sci. 8(08): 326-335. doi: https://doi.org/10.20546/ijcmas.2019.808.037 